\title{
Cell Division Cycle 7-Related Protein Kinase
}

National Cancer Institute

\section{Source}

National Cancer Institute. Cell Division Cycle 7-Related Protein Kinase. NCI Thesaurus. Code C28678.

Cell division cycle 7-related protein kinase ( $574 \mathrm{aa}, \sim 64 \mathrm{kDa}$ ) is encoded by the human CDC7 gene. This protein plays a role in protein phosphorylation and regulation of the cell cycle. 